\title{
Gas Chromatography Mass Spectrophotometry Analysis Report about Pumpkin (Cucurbita maxima, Cucurbitaceae) Flowers
}

\author{
Alhassan MA ${ }^{1}$, Siddig Ahmed $\mathrm{HH}^{1}$ and Salwa ME Khogali2* \\ ${ }^{1}$ Faculty of Pharmacy, The National Ribat University, Sudan \\ ${ }^{2}$ Central Veterinary Research Laboratory, Sudan
}

*Corresponding author: Salwa ME Khogali, Central Veterinary Research Laboratory, Alamara-Khartoum, Sudan, Tel: 00249922569395; Email: salwamuhamed@hotmail.com

\section{Research Article \\ Volume 2 Issue 2}

Received Date: July 26, 2018

Published Date: August 14, 2018

\section{Abstract}

This Study was done to investigate the phytochemical and antimicrobial activities of pumpkin flowers extracts (ethanolic, chloroform and ether extract -by using GC-MS methods to degrade the active components in the ethanol extracted flowers. Pseudomonas aeruginosa growth was inhibited only by chloroform fraction; ether fraction has activity against Escherichia coli and Staphylococcus aereus. Chloroform has no activity against Staphylococcus aereus. Nine constituents were degraded by Gas Chromatography Mass Spectrophotometry (GC-MS) analysis. Their structure and formulae were pertaining to the GC-MS analysis of pumpkin flowers were given in table and Figure 2.

Keywords: Gas Chromatography Mass Spectrophotometry (GC-MS) analysis; Phytochemical screening test; Antimicrobial activity test; Palmitic acid

\section{Introduction}

The pumpkin is a gourd of the genus Cucurbita and the family Cucurbitaceae, it is refers to cultivars of any one of the species Cucurbita pepo or Cucurbita maxima [1].

\section{Pumpkin Flowers}

The big, bright, yellow colourful flowers of pumpkin are often produced in abundance, especially the male flowers when compared to number of the female flowers. Pumpkin is hermaphrodite has both male and female flowers in the same plant, the female flower is distinguished by the small ovary at the base of the plant, these flowers have extremely short life spans and only open for as short as time as one day [2].

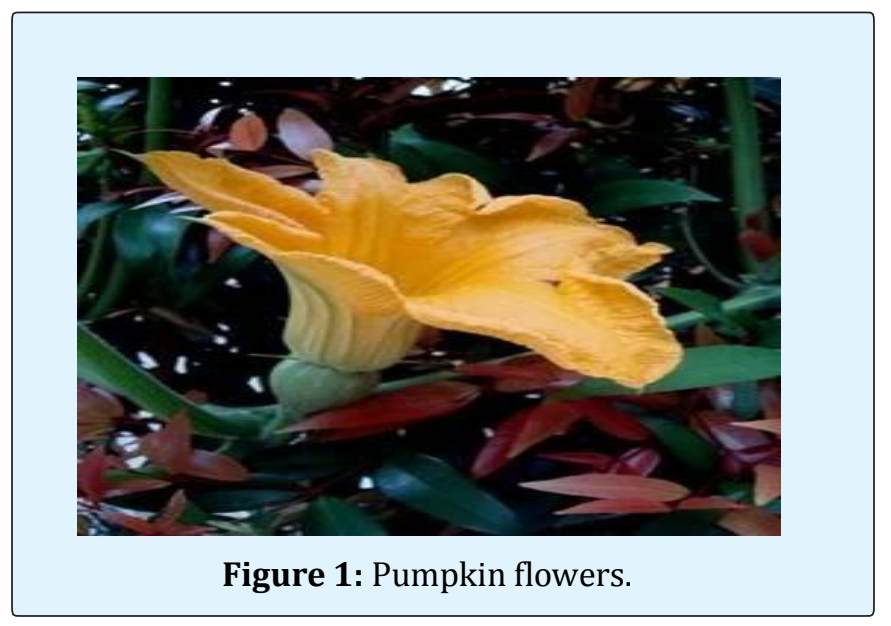




\section{Medicinal \& Analytical Chemistry International Journal}

\section{Pumpkin in Quran \& Sunnah}

Pumpkin mentioned in Quran Allah says: ((and we caused by a tree of gourd to grow over him)) [3] (Alsaaffat, 146), as the wisdom of the god in the pumpkin to germinate pumpkin plant on the prophet Yunus for food and healing.

The Mufassirin (commentators) said: The gourd (alYaqtin) is a kind of pumpkin. Some of them described the benefits of the pumpkin, such as: it grows quickly, it provides shade and it has large, smooth leaves, it keeps flies away and its fruit provides good nourishment: it can be eaten raw or cooked. It is known that the Messenger of Allah (peace and blessings be upon him) liked this kind of pumpkin and used to look for it on the plate of food [4].

\section{Current Uses of Pumpkin Flowers}

Popularity of pumpkin flowers in various systems of traditional medicine for several uses as:

a) Good for skin as Emollient and used as poultice, applied to burns, inflammations, boils, and burns [5].

b) Photo protective.

c) A Rich Source of Healthful Minerals and Protein.

d) As a protective and anticancer agent.

e) Anti-oxidant activities.

f) Has cardio-benefit, lower cholesterol.

g) Lower blood pressure, alleviate insulin resistance.

\section{Materials and Methodology}

\section{The Plant}

A pumpkin Flowers was collected from the local farm of Khartoum city in February 2012; authenticated, dried at shade and reduced to fine powder using pestle and mortar in the laboratory as described by Bean AR [6]. The powder was stored dry, and used as the stock sample for further analyses.

\section{Instruments and Chemicals}

A wide range of instruments and chemical were used during the course of this study.

\section{Method}

In this study all experiments were divided into four main parts:

a) Extraction of all active constituents in pumpkin flowers using ethanol as solvent.

b) Phytochemical screening test and antimicrobial activity tests.

c) GC-Ms analysis for pumpkin flowers extract.

d) The structure activity relationship and correlation between the detected active constituents and the traditionally reported uses of the pumpkin flowers.

\section{Generally, GC Analysis Conditions}

We were likely need to optimize GC conditions depending on their analytical needs, equipment, and sample type.

In general, a typical gas chromatography method will include:

a) Column: HP-5 MS 30m length, inner diameter $0.25 \mathrm{~mm}$, $0.25 \mathrm{~mm}$ film thickness.

b) Temperature program: $110^{\circ} \mathrm{C}$ to $280^{\circ} \mathrm{C}$ at a rate of $10^{\circ} \mathrm{C} / \mathrm{min}$.

c) Injector temperature $250^{\circ} \mathrm{C}$.

d) Injection volume: $2 \mu \mathrm{l}$.

e) Carrier gas: helium at a constant flow rate of $1 \mathrm{ml} / \mathrm{min}$.

\section{Results}

\section{Phytochemical and antimicrobial result of pumpkin flowers}

Pseudomonas aeruginosa growth was inhibited only by chloroform fraction; ether fraction has activity against E.coli and Staphylococcus aereus. Chloroform has no activity against Staphylococcus aereus.

\section{GC-MS Analysis Result of Pumpkin flowers}

This investigation was carried out to determine the possible chemical components from pumpkin flowers by GC-MS. The results pertaining to the GC-MS analysis of pumpkin flowers were given in table and figure below 


\begin{tabular}{|c|c|c|c|}
\hline No & Name & Formula & Structure \\
\hline 1 & Palmitic acid & $\mathrm{C}_{16} \mathrm{H}_{32} \mathrm{O}_{2}$ & \\
\hline 2 & Oxalic acid allyl octyl ester & $\mathrm{C}_{13} \mathrm{H}_{22} \mathrm{O}_{4}$ & \\
\hline 3 & 8,11,14- Eicosatrienoic acid & $\mathrm{C}_{20} \mathrm{H}_{34} \mathrm{O}_{2}$ & \\
\hline 4 & $\begin{array}{l}\text { Oxalic acid allyl tridecyl } \\
\text { ester }\end{array}$ & $\mathrm{C}_{18} \mathrm{H}_{32} \mathrm{O}_{4}$ & \\
\hline 5 & $\begin{array}{l}\text { Oxalic acid, allyl hexadecyl } \\
\text { ester }\end{array}$ & $\mathrm{C}_{21} \mathrm{H}_{38} \mathrm{O}_{4}$ & \\
\hline 6 & Stigmasta-7, 16- dien-3-ol & $\mathrm{C}_{29} \mathrm{H}_{48} \mathrm{O}$ & \\
\hline 7 & Stigmast-7-en-3-ol & $\mathrm{C}_{29} \mathrm{H}_{50} \mathrm{O}$ & \\
\hline
\end{tabular}

Table 1: The Name, Formula and Structures of phyto-chemical components detected in Pumpkin flowers by GC-MS. 


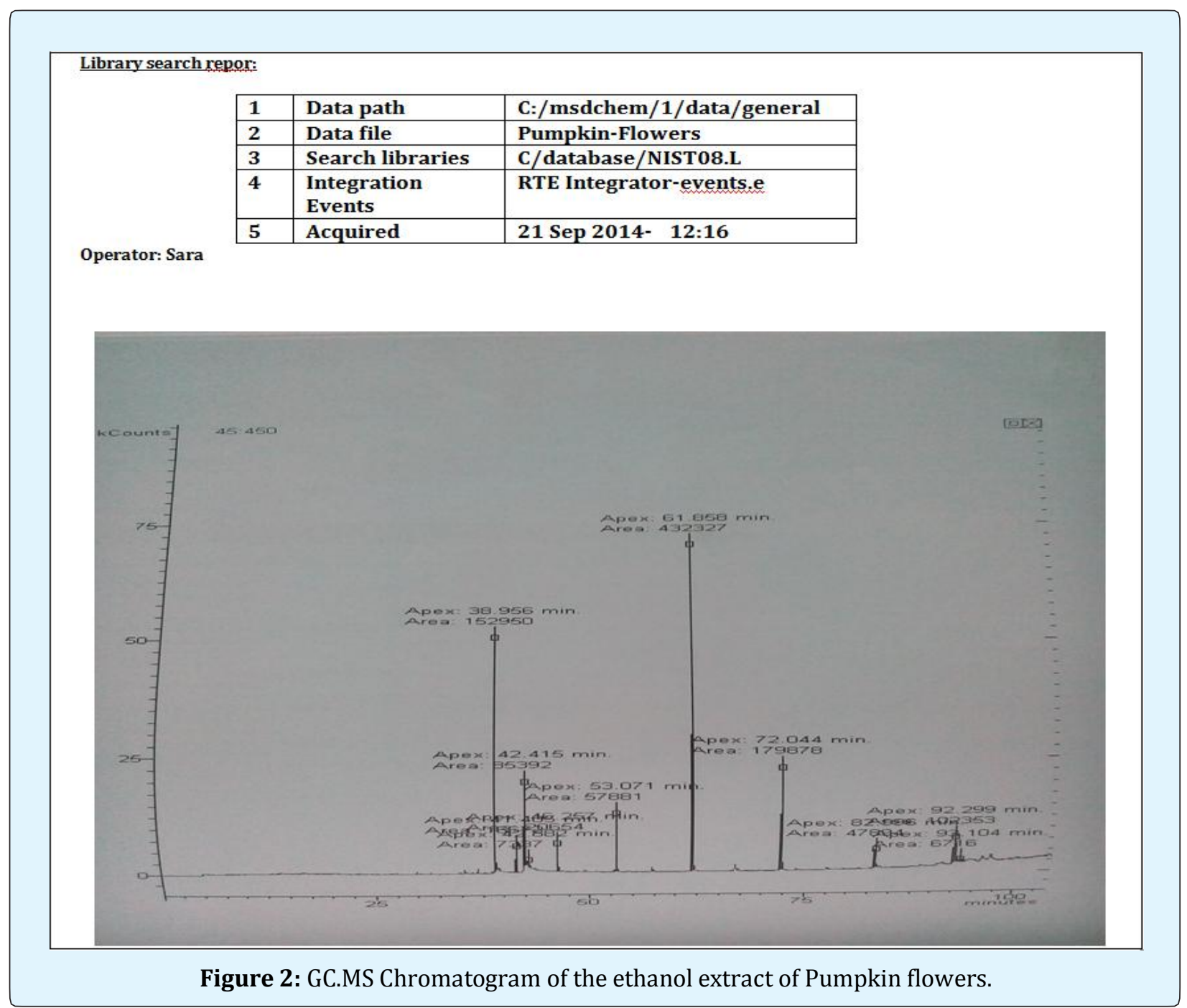

\section{Discussion}

Miracles from Quran represent a real challenge in discovering of chemical ingredients and its relationship with remedies. Selection of pumpkin within billion of plants did not come by chance but it was an indirect message from God to search in-depth in the mysteries and secrets of this great plant and through this work, nineteen natural chemical compounds have been detected in the investigated part of pumpkin (flowers), they need more efforts and deep analysis and interpretation to elucidate them in the plant. Through the presence of all these natural chemical compounds in pumpkin flowers can clearly see the extent of role of pumpkin flowers in the therapy and to grow around the prophet Yunus (pbuh).
The phytochemical compounds in the flowers of pumpkin extracted with ethanol screened by GC-MS method, 9 bioactive phytochemical compounds were identified. These different active phytochemicals have been found to possess a wide range of activities, which may help in the protection against numerous diseases.

\section{Activity of the Identified Phytochemicals in Pumpkin Flowers}

Palmitic acid: According to a Korean study published in a 2010 edition of the "Journal of Medicinal Food," palmitic acid posses antioxidant properties and can help to prevent atherosclerosis (hypo-cholesterolemic). Also it has antitumor activity with selective cytotoxicity to 


\section{Medicinal \& Analytical Chemistry International Journal}

cancer cells and not cytotoxic to the normal human cells, suggesting that palmitic acid may be a lead compound of anticancer drugs [7]. In moisturizers, palmitic acid is a very good emollient just as many other naturallyoccurring fatty acids, it helps reinforce skin's healthy barrier function for a smoother surface good for skin (decrease aging by as much as $56 \%$ ) also it has ability to fight skin cancer. Palmitic acid is known to have potential antibacterial and antifungal activities [8].

Oxalic acid esters: Is an important element to stimulate and maintain the peristaltic motion in our gut [9].

8, 11, 14- Eicosatrienoic acid: It is omega- 3- poly unsaturated fatty acid, potent antioxidant, has cardiobenefit, lower cholesterol, reduce depression, lower blood pressure, alleviate insulin resistance, improve brain function and boost children concentration levels. Also known to have anti- inflammatory properties and essential for normal growth and development [10].

5- Stigmasta-7, 16- dien-3-ol and Stigmast-7-en-3-ol: It is B- sistosterol like cholesterol structure use for insulin resistance diabetes (potent anti-diabetic agent i.e. stimulates glucose transport) and induces antiproliferation in human leukaemia [11].

\section{Conclusion}

As a consequence of all these bioactive nine compounds and their important biological activities, Allah Almighty had chosen the pumpkin tree for the prophet Yunus (pbuh) because of its benefits and usefulness in the large scale in recovering health and strength, and because of the presence of several beneficial active ingredients. However, isolation of individual phytochemicals and subjecting it to biological activity will definitely give fruitful results. The study revealed that pumpkin flowers studied was a potential food and has a multiple components medicine of benefits to the weak patients.

\section{References}

1. Credo (2004) Pumpkin. The Columbia Encyclopedia.

2. Watson L, Dallwitz MJ (1992) The families of flowering plants: descriptions, illustrations, identification, and information retrieval.

3. The Holy Quran.

4. The beginning and the end of Abi Al-Fidaa Al-Hafiz bin Katheer Al-Damashqi. 1'st (Edn.), 1988.

5. Susan D, Van Arnum (1998) Vitamin A in KirkOthmer Encyclopedia of Chemical Technology. John Wiley, New York, pp: 99-107.

6. Bean AR (2006) Collecting and preserving plant specimens, a manual.

7. Harada H, Noro T, Kamei Y (1997) Selective antitumor activity in vitro from marine alge from japan coasts. Biol pharm Bull 20(5): 541-546.

8. McGaw LJ, Jäger AK, Van Staden J (2002) Isolation of antibacterial fatty acids from Schotia brachypetala. Fitoter 73(5): 431-433.

9. Clark HT, Davis AW (2011) oxalic acid anhydrous org. Synth 1: 421.

10. Baggott, James (1997) The divinyl methane pattern in fatty acids. Knowledge weaves, Salt Lake city, UT.

11. Wang HX, Ng TB (1999) Natural products with hypoglycaemic, hypotensive, hypocholestrolemic and antiatherosclerotic activities. Life Sci 65(25): 26632677.

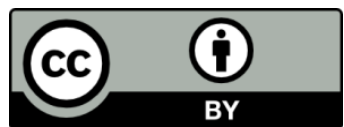

Salwa ME Khogali, et al. Gas Chromatography Mass Spectrophotometry Analysis Report about Pumpkin (Cucurbita maxima, Cucurbitaceae) Flowers. Med \& Analy Chem Int J 2018, 2(2): 000118. 